\title{
IL-27 induces the expression of IDO and PD-L1 in human cancer cells
}

\author{
Grazia Carbotti ${ }^{1}$, Gaia Barisione ${ }^{1}$, Irma Airoldi², Delia Mezzanzanica ${ }^{3}$, Marina \\ Bagnoli $^{3}$, Simone Ferrero ${ }^{4}$, Andrea Petretto ${ }^{5}$, Marina Fabbi ${ }^{1}$ and Silvano Ferrini ${ }^{1}$ \\ ${ }^{1}$ Department of Integrated Oncological Therapies, IRCCS AOU San Martino-IST Istituto Nazionale per la Ricerca sul Cancro, \\ Genoa, Italy \\ ${ }^{2}$ Laboratory of Oncology, Istituto Giannina Gaslini, Genoa, Italy \\ ${ }^{3}$ Department of Experimental Oncology and Molecular Medicine, Fondazione IRCCS Istituto Nazionale dei Tumori, Milan, Italy \\ ${ }^{4}$ Department of Surgery, Unit of Obstetrics and Gynaecology, IRCCS AOU San Martino-IST Istituto Nazionale per la Ricerca \\ sul Cancro, and DINOGMI, University of Genoa Genoa, Italy \\ ${ }^{5}$ Core Facilities, Istituto Giannina Gaslini, Genoa, Italy \\ Correspondence to: Silvano Ferrini, email: silvanodomenico.ferrini@hsanmartino.it \\ Marina Fabbi, email: marina.fabbi@hsanmartino.it
}

Keywords: IL-27, IDO, PD-L1, STAT, Immunology and Microbiology Section, Immune response, Immunity

Received: July 08, $2015 \quad$ Accepted: November 30, $2015 \quad$ Published: December 09, 2015

\section{ABSTRACT}

IL-27 is a member of the IL-12 family that is produced by macrophages and dendritic cells. IL-27 inhibits the growth and invasiveness of different cancers and therefore represents a potential anti-tumor agent. By contrast, it may exert immuneregulatory properties in different biological systems. We reported that IL-27 induces the expression of the IL-18 inhibitor IL-18BP, in human Epithelial Ovarian Cancer (EOC) cells, thus potentially limiting the immune response. Here, we tested whether IL-27 may modulate other immune-regulatory molecules involved in EOC progression, including Indoleamine 2,3-dioxygenase (IDO) and Programmed Death-Ligand (PDL)1. IDO and PD-L1 were not constitutively expressed by EOC cells in vitro, but IL27 increased their expression through STAT1 and STAT3 tyrosine phosphorylation. Differently, cells isolated from EOC ascites showed constitutive activation of STAT1 and STAT3 and IDO expression. These findings, together with the expression of IL27 in scattered leukocytes in EOC ascites and tissues, suggest a potential role of IL27 in immune-regulatory networks of EOC. In addition, IL-27 induced IDO or PD-L1 expression in monocytes and in human PC3 prostate and A549 lung cancer cells. A current paradigm in tumor immunology is that tumor cells may escape from immune

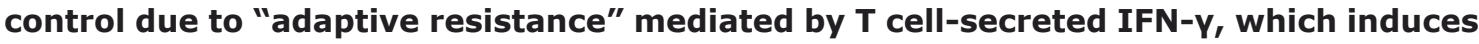
PD-L1 and IDO expression in tumor cells. Our present data indicate that also IL-27 has similar activities and suggest that the therapeutic use of IL-27 as anti-cancer agent may have dual effects, in some tumors.

\section{INTRODUCTION}

Immune-regulatory mechanisms play a crucial role in cancer progression, as they limit the anti-tumor immune response [1,2]. For example, the expression of Programmed Death-Ligand (PD-L) 1 by cancer cells impairs $\mathrm{T}$ cell functions through the engagement of its receptor PD-1 at the T cell surface [3]. In addition, the enzyme Indoleamine 2,3-dioxygenase (IDO) is expressed in neoplastic cells and tumor-associated leukocytes or dendritic cells, and its expression correlates with a shorter survival, in different cancers [4]. IDO induces T cell dysfunction and apoptosis through the depletion of tryptophan and the generation of kynurenine [5].

Several experimental models and clinical studies in cancer patients indicate that targeting of immuneregulatory mechanisms may restore the immune response and mediate therapeutic effects. Recently, immune- 
enhancing monoclonal antibodies (mAbs) that target immune check-points such as anti-PD-1 and anti-PD-L1 have shown clinical benefit in different cancers $[1,2,6$, 7]. Although immunotherapy has been primarily proposed for "immunogenic" tumors, such as melanoma and renal cancer, anti-PD-L1 or anti-PD-1 blocking mAbs are currently being studied also in other cancers, including Epithelial Ovarian Cancer (EOC). Indeed, the immune system can recognize EOC cells [8,9] because CTLs able to lyse EOC cells are present at the tumor site [10] and recognize different EOC-associated antigens [11]. Moreover, high tumor-infiltrating $\mathrm{T}$ cell counts have a positive impact on the clinical course of EOC [12-15].

We recently reported that IL-18 Binding Protein (IL18BP), an inhibitor of the immune-enhancing cytokine IL-18 [16], is elevated in the serum and ascites of EOC patients [17]. IL-18BP is expressed in primary EOC and tumor-associated leukocytes in vivo, but not in human EOC cell lines, where it may be induced by stimulation with IFN- $\gamma$ or IL-27. Thus, these cytokines may participate in vivo in an immune-regulatory network involving IL18BP. Similar to IL-18BP, EOC cells express IDO in vivo, but not in culture, where it can be induced by IFN- $\gamma$ stimulation [18]. In addition, IFN- $\gamma$ mediates the induction of IDO and PD-L1 in both cancer and normal cells [1921]. These effects may represent the outcome of a feedback circuit, which counter-regulates the immune response and may lead to adaptive immune-resistance of tumors [1$3,22,23]$.

The possible role of IL-27 in immune-regulatory networks in cancer is still poorly understood [24, 25]. IL-27, a member of the IL-12 family, is a heterodimer, consisting of p28 (IL-27A) and EBV-induced gene 3 (EBI3) chains $[24,26]$. IL-27 induces the proliferation of CD4+ T cells [27] and up-regulates IL-12R expression thus supporting Th1 polarization [28]. In addition, it directly inhibits growth or invasiveness of different cancer cells [29-34] and has immune-enhancing activity in different tumor models in vivo [35-38]. Altogether these findings support the potential use of IL-27 as anticancer agent [39]. However, IL-27 has anti-inflammatory and immune-regulatory functions and may limit some immune-mediated diseases [40-43]. For example, priming of naïve $\mathrm{T}$ cells in the presence of IL-27 converts them into PD-L1-expressing regulatory T cells, which limit IL17 production [43].

To better characterize the role of IL-27 in regulating immune suppressive molecules in cancer, we investigated its ability to induce IDO and PD-L1 in EOC and other cancer cells.

\section{RESULTS}

\section{IL-27 induces IDO expression in human EOC cell lines}

IDO is involved in immune-suppressive circuits in EOC and several groups reported that it is expressed in EOC tissues [44-48]. As shown in Figure 1A, EOC cell lines do not constitutively express IDO protein, as detected by Western blot. However, if human A2774 EOC cells are implanted in SCID mice, IDO expression is observed in the engrafted tumor cells (Figure S1). These data suggest that factors produced within the tumor environment, different from murine IFN- $\gamma$, which is inactive on human cells, may induce IDO expression. As EOC cell lines are responsive to IL-27 [17], we asked whether IDO expression may be modulated by IL-27 in a panel of 6 cell lines representative of different sub-types of this cancer (Table S1) [49, 50]. As shown in Figure 1A both IFN- $\gamma$ and IL-27 induce IDO protein expression in all the cell lines, with the exception of one (A2780). Accordingly, IL-27 strongly increases IDO mRNA expression from 9 to $>10,000$ fold in all cell lines, but only marginally in A2780 cells (Figure 1B). Of note, IDO protein is enzymatically active as witnessed by the increase in kynurenine concentration in the conditioned media of IL-27- or IFN- $\gamma$-treated cells (Figure 1C), and, consistently, A2780 cells show minimal changes in kynurenine release upon cytokine stimulation. The inability of IL-27 to induce IDO expression in A2780 cells is not related to defective signaling, as our previous data showed that these cells respond to IL-27 by upregulating STAT1 phosphorylation and IL-18BP mRNA and protein expression [17]. In addition, also IFN- $\gamma$ failed to induce IDO expression in A2780 cells, suggesting that this cell line may have specific defects in IDO gene expression. Finally, we tested whether other members of the IL-12 cytokine family, sharing one of the two subunits of IL-27 (IL-27A or EBI3) may induce IDO in EOC cells. As shown in Figure 1A, IL-30, IL-35 or EBI3 failed to stimulate IDO expression in three IL-27-responsive cell lines. In addition, also the IFN- $\gamma$-inducing cytokine IL-12 and the GP130-signalling cytokines IL-6 and IL-11 failed to induce IDO expression (Figure S2) thus indicating that IDO induction in EOC cells is a unique feature of IL-27, among these cytokines.

\section{IL-27 up-regulates PD-L1 expression in human EOC cells}

PD-L1 is a major cell surface immune-regulatory molecule in EOC [14, 51-54], as well as in other tumors, where it can be expressed either constitutively or in response to IFN- $\gamma$ stimulation [20, 21]. As shown in Figure $2 \mathrm{~A}$, left panels, PD-L1 was not detected or was minimally 


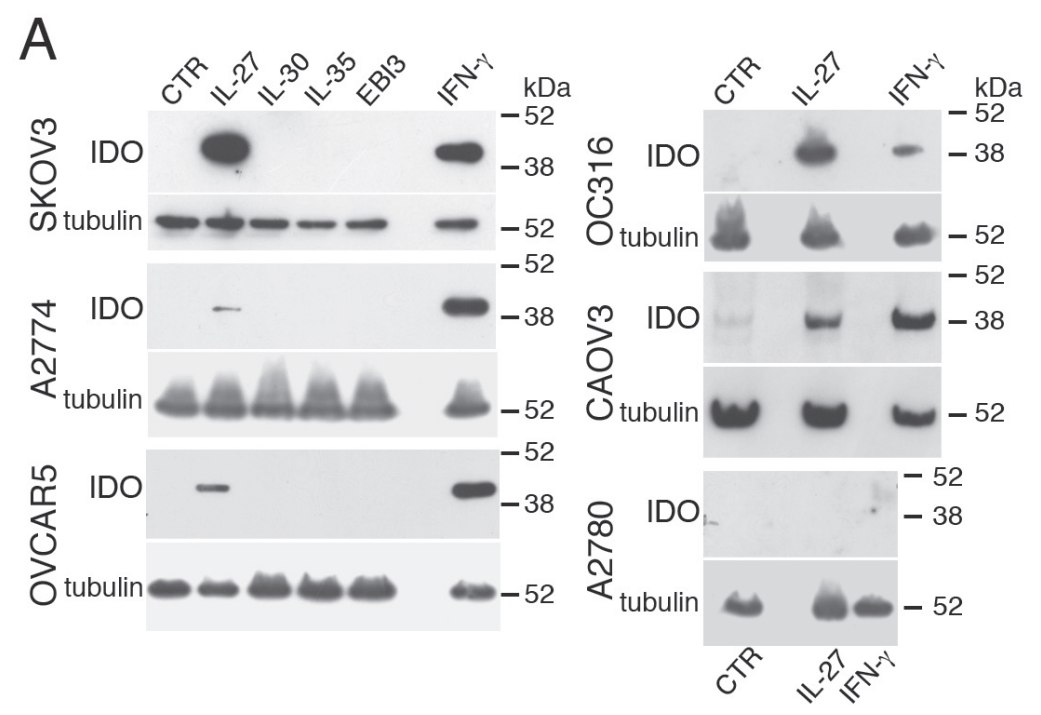

B

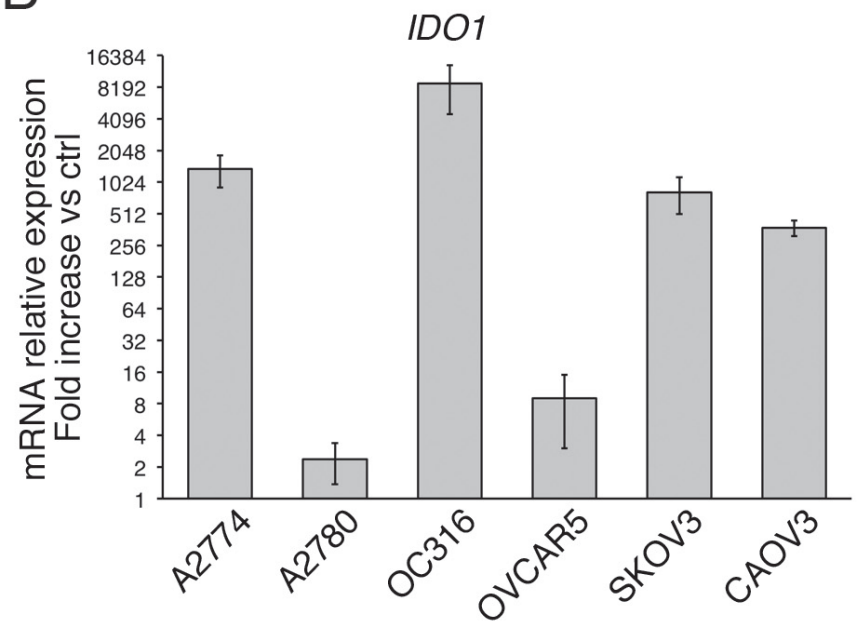

C

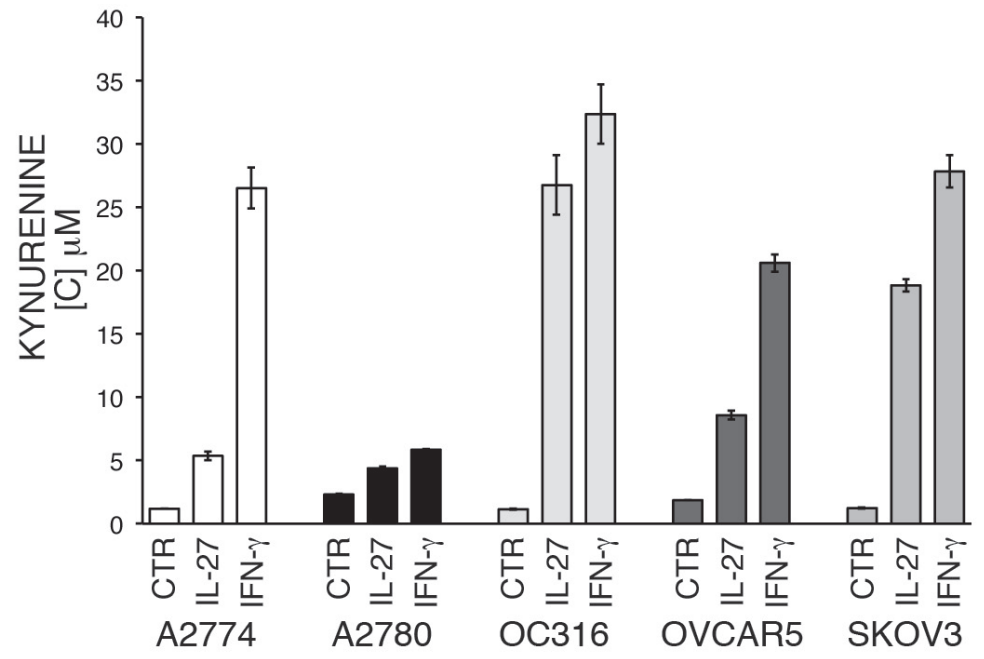

Figure 1: IL-27 induces IDO protein and mRNA expression in human EOC cells in vitro. A. Western blot analysis of IDO expression in six EOC cell lines stimulated with the indicated cytokines or medium only (CTR) for 48 hours. $\alpha$-tubulin is used as loading control. A representative experiment out of two is shown. B. QRT-PCR analysis of IDOI mRNA expression in EOC cells treated with IL27 relative to untreated (Ctrl) cells. Data are the mean of three independent experiments and expressed as $\Delta \Delta \mathrm{CT}$-fold change. Error bars represent SD. C. Kynurenine production in the conditioned medium of IL-27, IFN- $\gamma$ or untreated (CTR) EOC cells, as detected by HPLC analysis. Histograms represent mean values of three biological replicates and error bars are standard deviations. 
expressed at the surface of EOC cell lines (control), as assessed by FACS analysis. However, both IFN- $\gamma$ and IL27 increased PD-L1 surface expression in 4 out of six cell lines analyzed (Figure 2A), while only minor induction was observed in the other two cell lines (not shown). In addition, IL-27 increased $P D L 1$ gene expression by 4 to 60 -fold in the 6 EOC cell lines (Figure $2 \mathrm{~B}$ and 2C), although this up-regulation was in general less evident than that of IDO gene (a representative EOC cell line, CAOV3, is shown in Figure 2C).

Altogether the biological activity of IL-27 in EOC cells suggested that it should act through the GP130/ WSX1 receptor complex. Indeed, both GP130 and WSX1/ IL-27RA receptor chains were detected in all cell lines by immunofluorescence (Figure 3).
We also asked whether IFN- $\gamma$ and IL-27 could cooperate in inducing PD-L1 expression. A cooperative effect was indeed found both at sub-optimal (e.g. $100 \mathrm{IU} / \mathrm{ml} \mathrm{IFN-} \gamma$ and $10 \mathrm{ng} / \mathrm{ml}$ of IL-27) and at high concentrations $(1,000 \mathrm{IU} / \mathrm{ml} \mathrm{IFN}-\gamma$ and $100 \mathrm{ng} / \mathrm{ml}$ of IL27) (Figure S3).

\section{Role of STAT1 and STAT3 in IDO and PD-L1 regulation}

IL-27 signals through STAT1 and STAT3 in different cell types [24]. IL-27 induced activation of both STAT1 and STAT3 through tyrosine phosphorylation also in EOC cells at 10-30 min after stimulation (Figure 4A
A
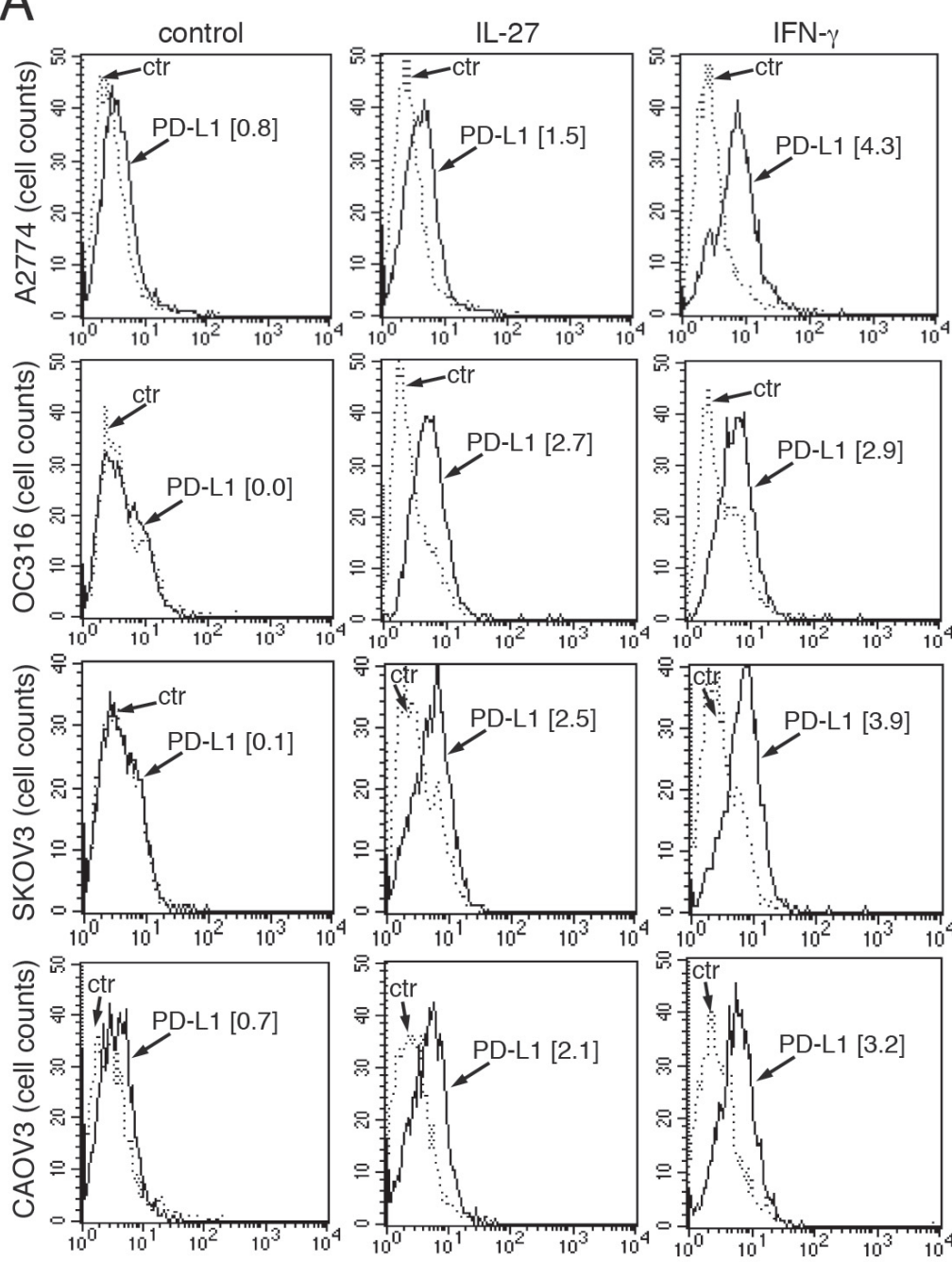

Log Fluorescence Intensity
B
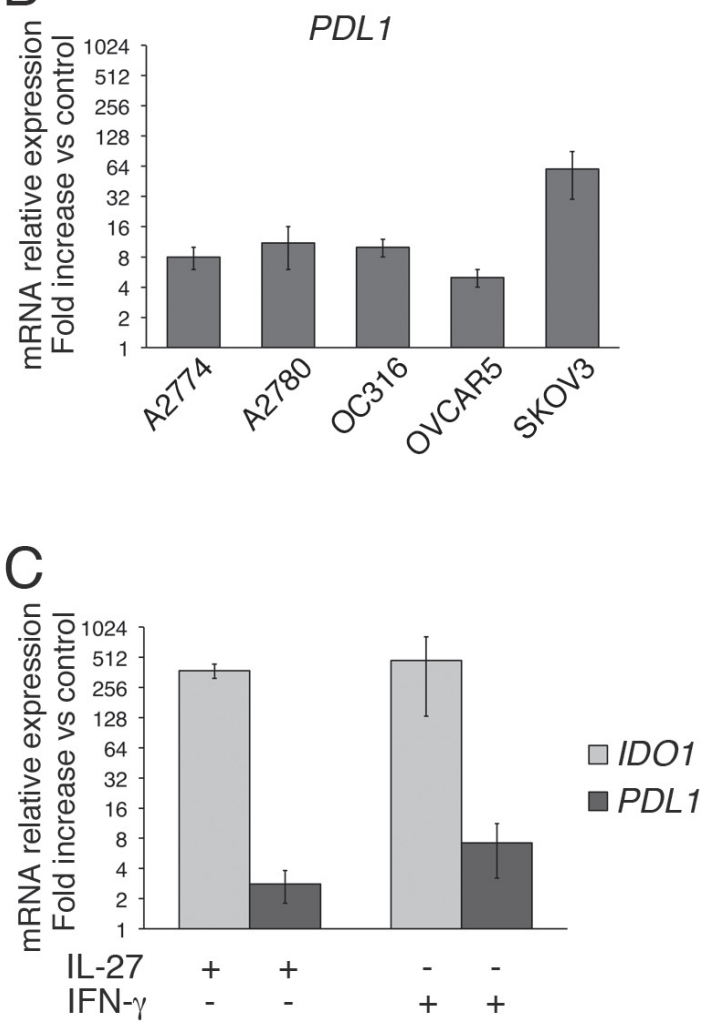

Figure 2: IL-27 increases PD-L1 surface protein and mRNA expression in EOC cells in vitro. A. FACS analysis of surface PD-L1 expression in four EOC cell lines, cultured in the presence of medium (control), IL-27 or IFN- $\gamma$. Dotted lines are isotype-matched unrelated Ig staining controls. Numbers in brackets are Median Fluorescence Intensity (MFI) values calculated as median PD-L1 minus median Ig control. Data are representative of two independent experiments showing similar results. B. QRT-PCR analysis of PDL1 mRNA expression in five IL-27-stimulated EOC cells relative to untreated cells. Data are the mean $( \pm \mathrm{SD})$ of three independent experiments. C. Comparative analysis of IDO1 and PDL1 mRNA up-regulation by IL-27 or IFN- $\gamma$ in a representative EOC cell line (CAOV3). Data are the mean of two independent replicates and are expressed as $\Delta \Delta \mathrm{CT}$-fold change. Error bars represent the minimum and maximum. 
and 4B). Moreover, cell populations, isolated from the ascites of three different patients, showed a constitutive phosphorylation/activation of STAT1 and STAT3 paralleled by IDO protein expression (Figure 5A). An additional control experiment showed the constitutive phosphorylation of STAT1 and STAT3 in cells isolated from ascites but not in a control, un-stimulated EOC cell line (Figure S4). By IHC, both tumor cell nests and scattered reactive cells contribute to IDO expression (Figure 5B). It is of note that immunohistochemical
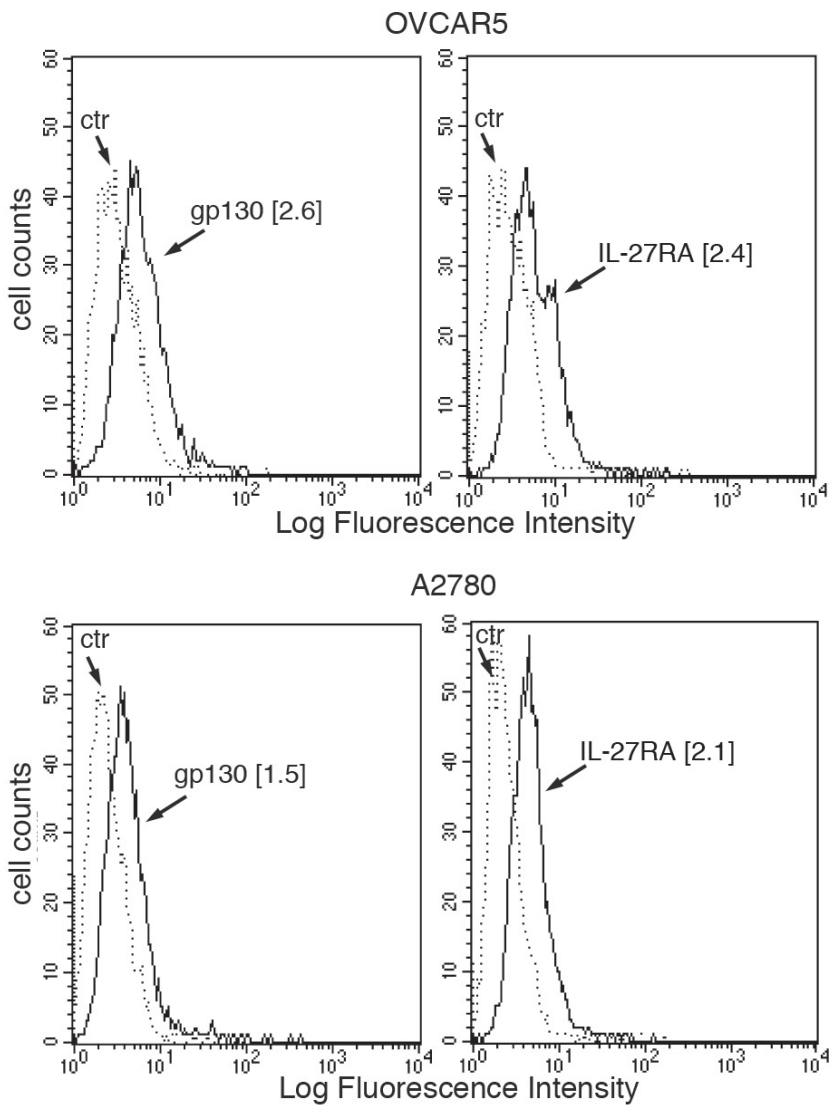

CAOV3

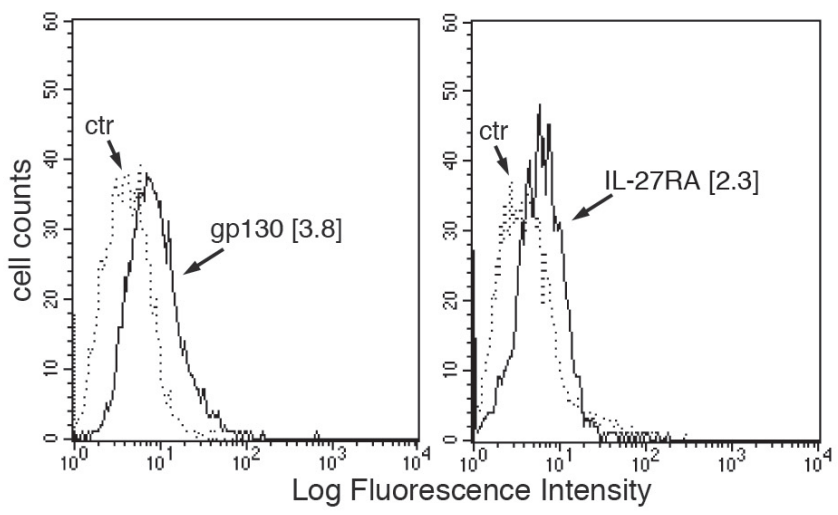

analysis of human ovarian cancer specimen revealed that IL-27-producing leukocytes are also present in some tumor microvessels (Figure S5). In these samples IDO is expressed in the microvessel wall and in some scattered cells in the stroma, while PD-L1 was found also in tumor cells (Figure S5A). These findings, together with our previous observation that leukocytes in the ascites and scattered in EOC tissues express IL-27 [17], support the concept that IL-27 released in tumor microenvironment may induce IDO expression.
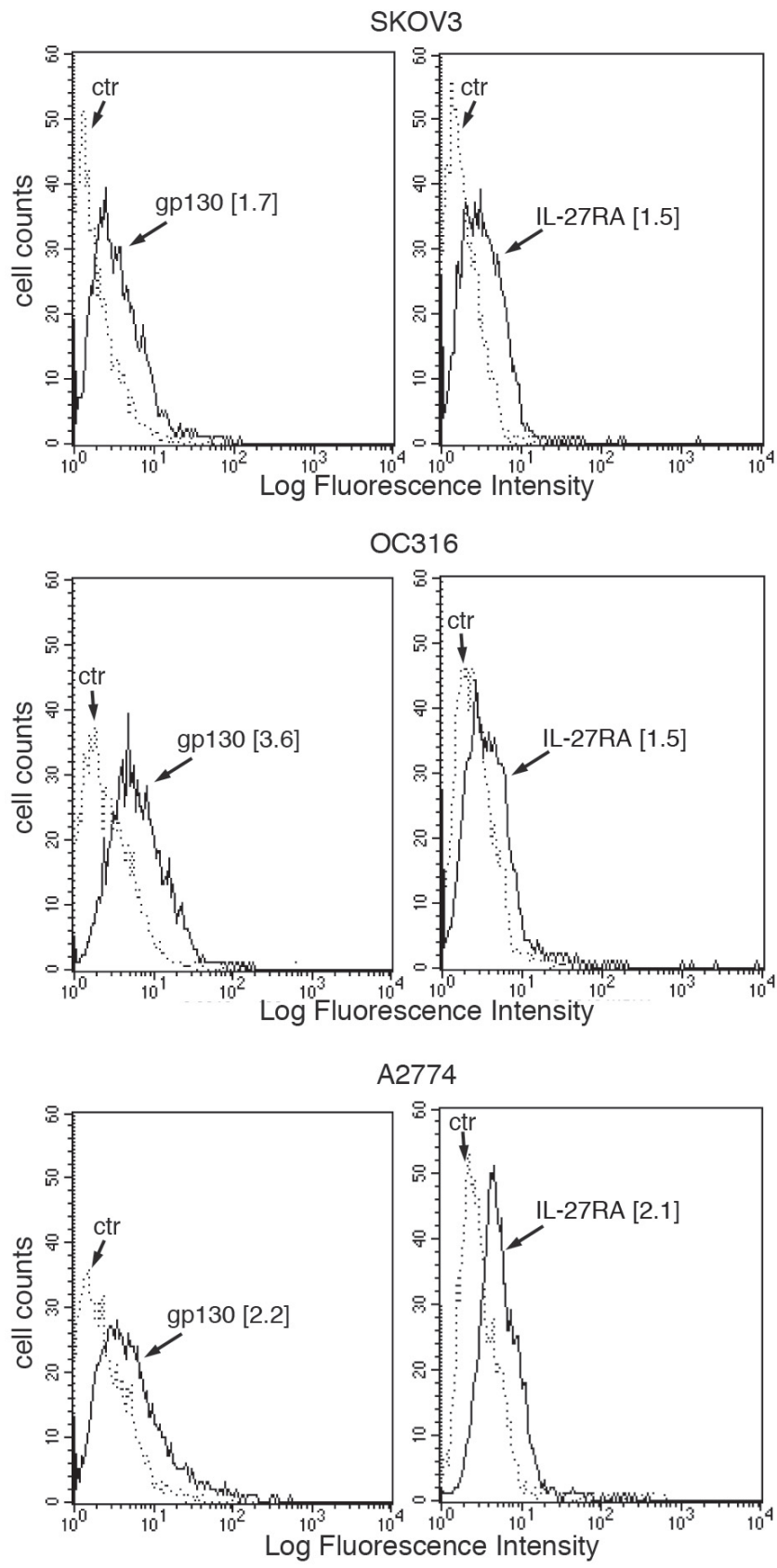

Figure 3: IL-27R chains GP130 and WSX1/IL-27RA are expressed in EOC cell lines. FACS analysis of surface GP130 and WSX1/IL-27RA expression in six EOC cell lines. Dotted lines represent isotype-matched unrelated Ig staining controls. Numbers in brackets are MFI values calculated as median GP130 or WSX1/IL-27RA minus median Ig control. Data are representative of two independent experiments with similar results. 
A

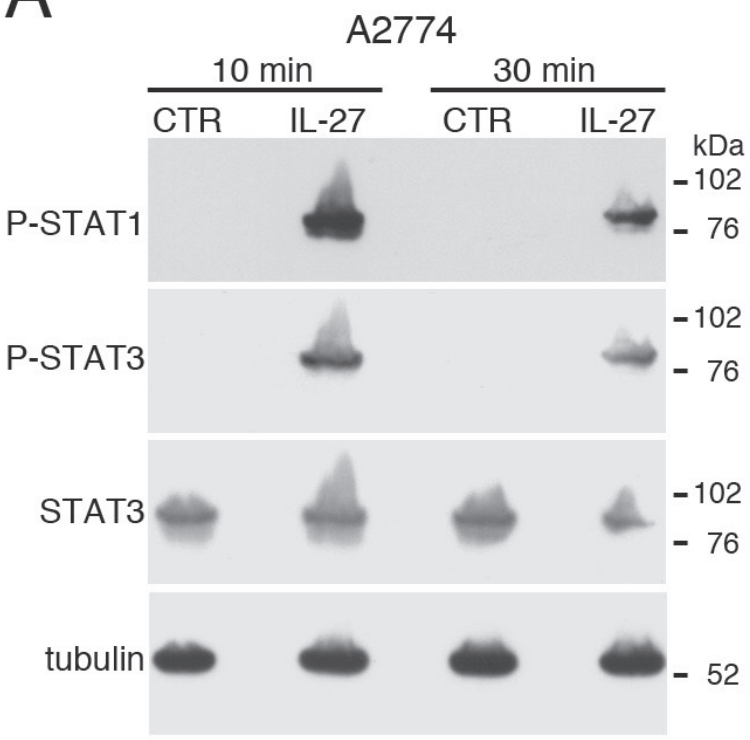

B

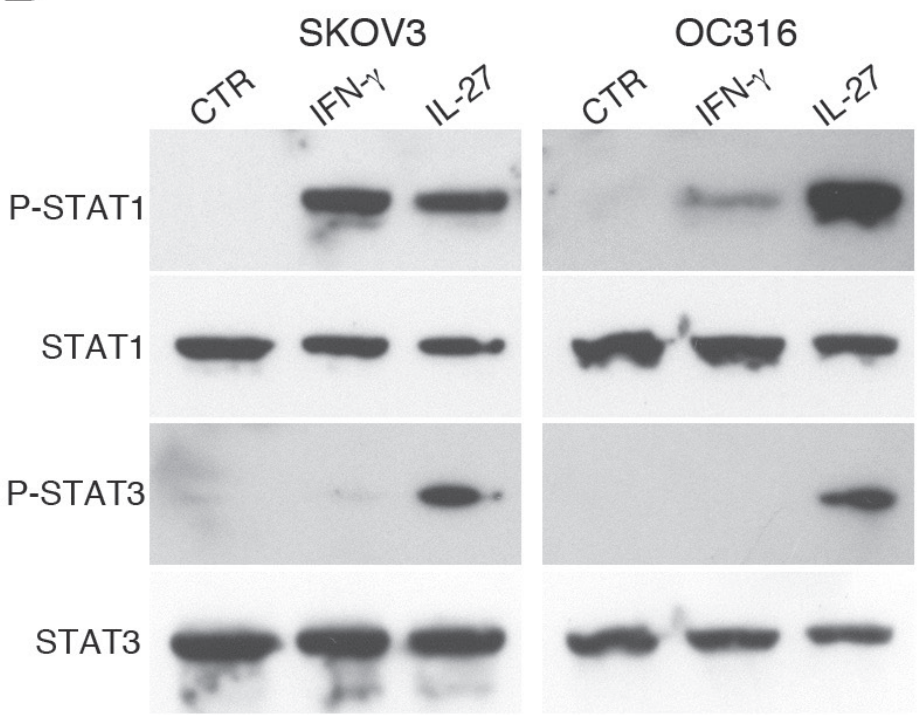

Figure 4: IL-27 induces STAT1 and STAT3 phosphorylation (P) in EOC cell lines in vitro. A. Western blot analysis of tyrosine phosphorylated (P)-STAT1, P-STAT3 and STAT3 proteins in A2774 EOC cells either cultured for 10 or 30 minutes with medium (CTR) or with IL-27 $(20 \mathrm{ng} / \mathrm{ml})$. Total STAT3 and $\alpha$-tubulin served as controls. Similar kinetics of STAT1/3 phosphorylation were observed in another cell line (A2780, not shown). B. Analysis of P-STAT1, STAT1, P-STAT3 and STAT3 proteins in SKOV3 and OC316 cell lines cultured in medium alone (CTR), or with IFN- $\gamma$ or IL-27 (20 minutes). Total STAT1 and STAT3 were used as controls. Data are representative of three independent experiments.

A

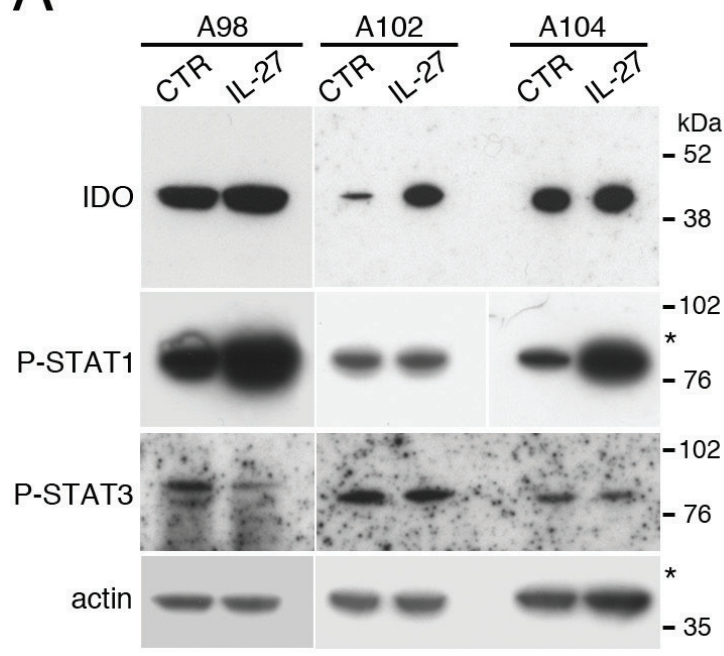

B

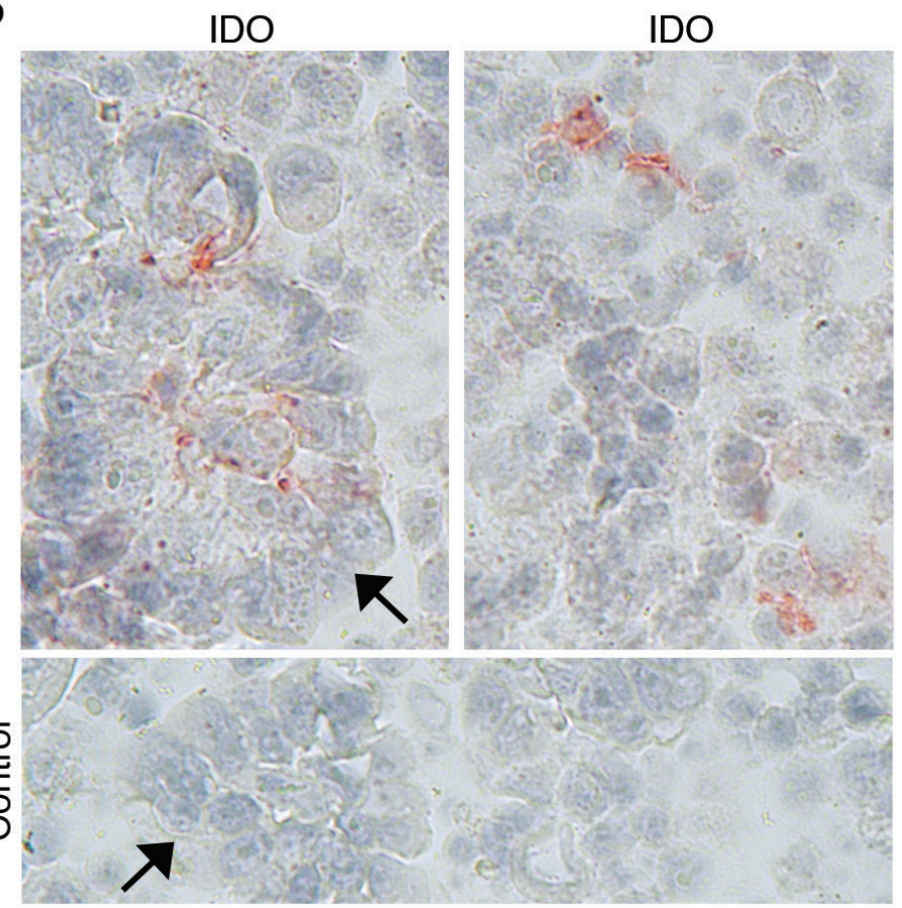

Figure 5: IDO and tyrosine-phosphorylated forms of STAT1 and STAT3 are constitutively present in cells from EOC ascites. A. Western blot analysis of IDO, P-STAT1 and P-STAT3 proteins in neoplastic cells isolated from the ascites of three ovarian cancer patients cultured with medium (CTR) or IL-27 for 20 minutes. $\beta$-actin was used as loading control. * indicate lanes from a blot reprobed for IDO and phosphorylated STAT3 for which STAT1 and actin were presented in a previous article [17]. B. Immunohistochemical analysis of IDO expression in ascites cells. Both tumor cell nests (arrow) and scattered reactive cells express IDO protein. 
As both STAT1 $[55,56]$ and STAT3 $[45,57]$ have been involved in IDO and PD-L1 up-regulation in different cell types, we silenced STAT1 or STAT3, by specific siRNA, in A2774 and OC316 EOC cell lines, which are responsive to IL-27. Then, we treated these cells with IL27 and analyzed them for IDO and PD-L1 expression. As expected, silencing of STAT1 strongly inhibited STAT1 expression and STAT1 phosphorylation induced by IL-27 treatment for $10 \mathrm{~min}$, without effecting STAT3 expression and phosphorylation (Figure 6A). Conversely, STAT3 siRNA silencing had specific effects only on STAT3, but not on STAT1. Cells transfected with non-targeting siRNA were used as controls. Parallel cultures, stimulated with IL-27 for $48 \mathrm{~h}$ after silencing, showed a strong inhibition of IDO induction, in STAT1- but not STAT3-silenced cells, where it appeared even up-regulated (Figure 6B and Figure S6A). Conversely, STAT1 silencing failed to inhibit IL-27-induced surface PD-L1 expression, which was instead sensitive to STAT3 down-regulation, in both OC316 and A2774 cells (Figure 6C). Similar results showing that STAT3 silencing significantly inhibits IL27-driven surface PD-L1 expression were obtained in replicate experiments (Figure S6B). Taken together, these results indicate that IL-27-driven up-regulation of IDO protein is predominantly STAT1-dependent, while PD-L1 is mainly regulated through STAT3 (Figure 6).

To verify whether the induction of IDO and PDL1 expression by IL-27 was limited to EOC cells or was a common feature shared with other cancer cell types and normal cells, we tested PC3 prostate cancer cells and A549 lung adenocarcinoma cells, both of which were shown to respond to IL-27 stimulation, and human monocytes. Indeed, monocyte-derived tumor-associated macrophages play a fundamental role in the development and progression of cancer [58] and may express IDO protein in the tumor environment [59]. We found that monocyte populations, enriched by adherence to plastic from human PBMC, showed increased expression of IDO protein (a representative experiment out of three is shown in Figure 7A, left panels) and mRNA (Figure 7B, left) upon stimulation with IL-27 or with IFN- $\gamma$. Conversely, no significant induction of IDO was detected in the nonadherent cell fraction of the same PBMC (Figure 7A).

Finally, human prostatic PC3 and lung A549 carcinoma cells showed enhanced IDO $\mathrm{mRNA}$ and protein expression, in response to IL-27 stimulation (Figure 7B and 7A, respectively), although induction of IDO protein was in general lower than in EOC cells. IL-27 increased also PD-L1 mRNA (Figure 7B right) and surface protein expression in PC3 and at a lesser extent in A549 cells, while it induced virtually no changes in surface PD-L1 in monocytes (Figure 7C).

\section{DISCUSSION}

Altogether these data show, for the first time, that
IL-27 induces IDO and PD-L1 expression in human EOC cancer cells through activation/phosphorylation of STAT1 or STAT3, respectively. Among the IL-12 cytokine family, induction of IDO in EOC cells was a unique property of IL-27 as the related cytokines IL-12, IL-35, IL-30 and EBI3 failed to modulate such molecule. In addition, also IL-6 and IL-11, which signal trough GP130 were inactive. IL-27 also induced the expression of IDO and PD-L1 in human PC3 prostate cancer cells and in A549 lung adenocarcinoma and monocyte-enriched populations, suggesting a broader effect of IL-27. It should be noted that induction of IDO protein appeared low in PC3 cells, while PD-L1 induction was weak in A549 and very marginal in monocytes. The importance of PD-L1 expression in cancer cells as a major immune escape mechanism in the tumor microenvironment is supported by the clinical benefit of PD-L1 and PD-1 blocking antibodies $[6,7]$. The current paradigm is that "adaptive" PD-L1 expression in tumor cells is induced by IFN- $\gamma$ released during CTL recognition of tumor cells [20-22]. Our data suggest that IL-27, a cytokine produced by macrophages or DCs, may provide an alternative stimulus for PD-L1 expression, in cancer cells.

The expression of the two IL-27 chains, IL-27A and $\mathrm{EBI} 3$, in tumor-associated leukocytes in EOC ascites and tumor tissues suggested a role of endogenous IL-27 in the microenvironment of this tumor [17]. Nontheless, the assessment of the real role of IL-27 in ovarian cancer biology would require further studies in suitable syngeneic models. In agreement with the hypothesis of a potential role of IL-27 in EOC, tyrosine phosphorylated forms of STAT1 and STAT3 could be detected in cells isolated from the ascites, although the role of other STAT1/3 activating cytokines cannot be excluded. STAT1 signaling is essential for IDO transcriptional regulation by interferons [60]. However, recent reports indicate that autocrine induction of IDO by IL-6 is STAT3-dependent in some cancer cells or in myeloid suppressor cells $[45,61]$, suggesting that cytokines may induce IDO expression through different STAT pathways.

These data suggest that IL-27 may contribute to the generation of an immune-suppressive tumor environment, which could dampen the immune response through induction of IL-18BP, IDO and PD-L1, and add to the complexity of its effects in cancer. Indeed, several observations indicate that IL-27 has a dual role in cancer and in immune-regulation and inflammation $[25,40]$. On one hand, IL-27 has been reported to display anti-inflammatory and immune suppressive effects. In fact, it induces expression of the ecto-ATPase CD39 on dendritic cells [62], IL-10 production [41, 63] and PD-L1 expression [43] in T cells and induction of Th1-like Treg cells [64]. These effects may limit autoimmune responses or anti-tumor immunity. Indeed, previous findings indicate that $I l 27-/-$ mice were more susceptible to experimental autoimmune encephalomyelitis than normal mice [42]. 

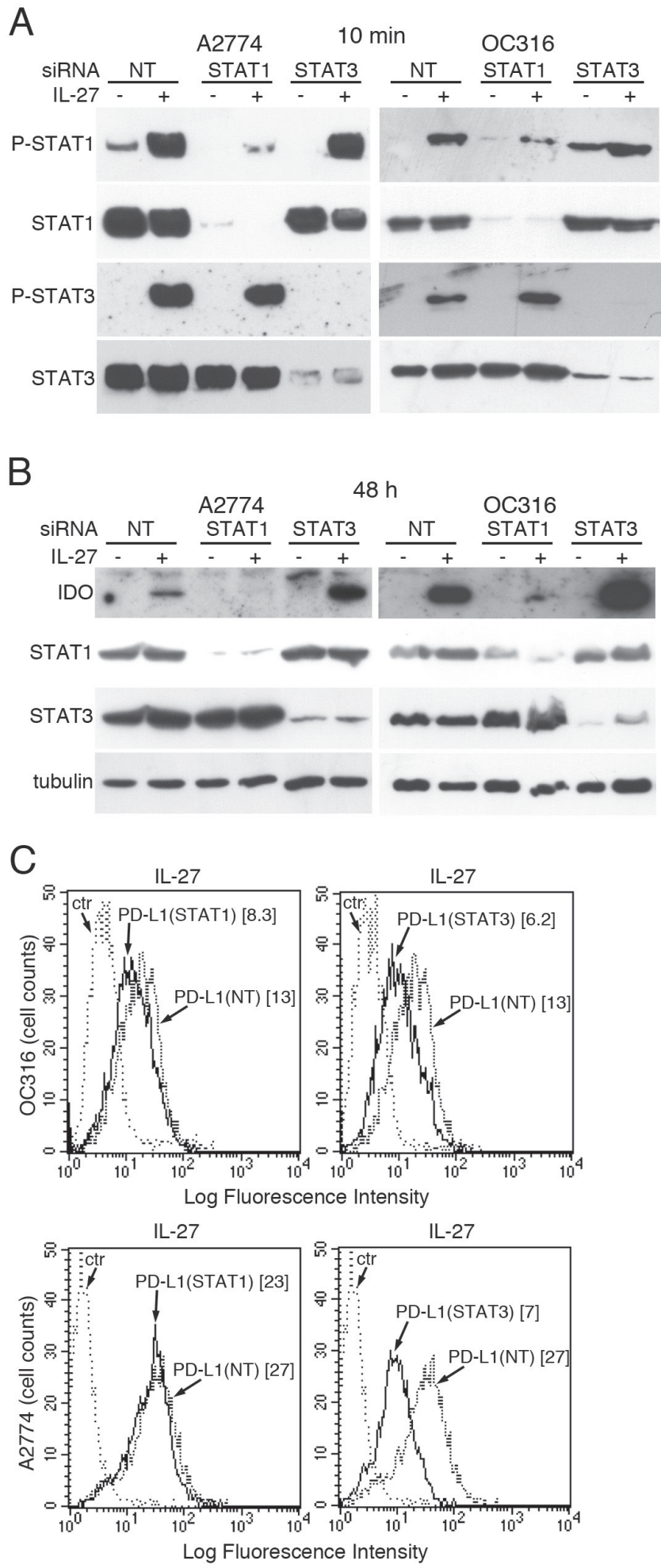

Figure 6: Silencing of STAT1 or STAT3 with siRNA effects IL-27-driven IDO or PD-L1 expression. A. Western blot analysis of STAT1 and STAT3 unphosphorylated and phosphorylated (P) proteins in STAT1- or STAT3-silenced or scrambled (NT) siRNAtransfected A2774 and OC316 EOC cells untreated or treated for 20 minutes with IL-27 $(20 \mathrm{ng} / \mathrm{ml})$. Total STAT3 or STAT1 served as controls for STAT1- or STAT3-silenced cells, respectively. B. Western blot analysis of IDO expression in STAT1- or STAT3-silenced or scrambled siRNA-transfected A2774 and OC316 EOC cells untreated or treated for 48 hours with IL-27 (50 ng/ml). $\alpha$-tubulin is shown as loading control. A replicate experiment is shown in Figure S6A C. FACS analysis of PD-L1 surface expression in STAT1- or STAT3silenced or scrambled siRNA-transfected OC316 or A2774 EOC cells untreated or treated for 48 hours with IL-27 (50 ng/ml). Numbers in brackets are MFI values calculated as median PD-L1 minus median Ig control. The results of different experiments are shown in Figure S6B. 
On the other hand, IL-27 has shown anti-tumor activity in different cancer models in vitro and in vivo, through different mechanisms, including direct effects on tumor cells or activation of an anti-tumor immune response [25]. For example, IL-27 directly inhibits proliferation and angiogenesis in B cell lymphoma, acute lymphoblastic leukemia, acute myeloid leukemia and multiple myeloma cells [65, 30, 29]. In addition, IL-27 inhibited in vitro and in vivo growth of prostate cancer cells and tumor angiogenesis [33] and also triggered anti-angiogenic responses through the induction of antiangiogenic chemokines in mouse melanoma models [66]. More recently, IL-27 was shown to down-regulate stemness- and EMT-related genes in non-small cell lung cancer cells and to trigger myeloid cell anti-tumor activities in xenotransplant tumor models [67].

In conclusion, the net effect of IL-27 as an antitumor agent may depend on the balance of multiple factors. IL-27 similar to other cytokines studied as potential anti-cancer agents, e.g. IL-18 [68] or IL-21 [69], may have a dual role in immune-regulation. Indeed, our data provide new evidence that, beyond its well known anti-tumor effects, IL-27 may also elicit immuneregulatory circuits, particularly in the tumor environment, through the induction of PD-L1 and/or IDO in EOC cells and monocytes. Collectively these data suggest that the combination of IL-27 with inhibitors of IDO or PD-L1/ PD-1 should enhance its anti-tumor effects and may be exploited in pre-clinical models of cancer immunotherapy.
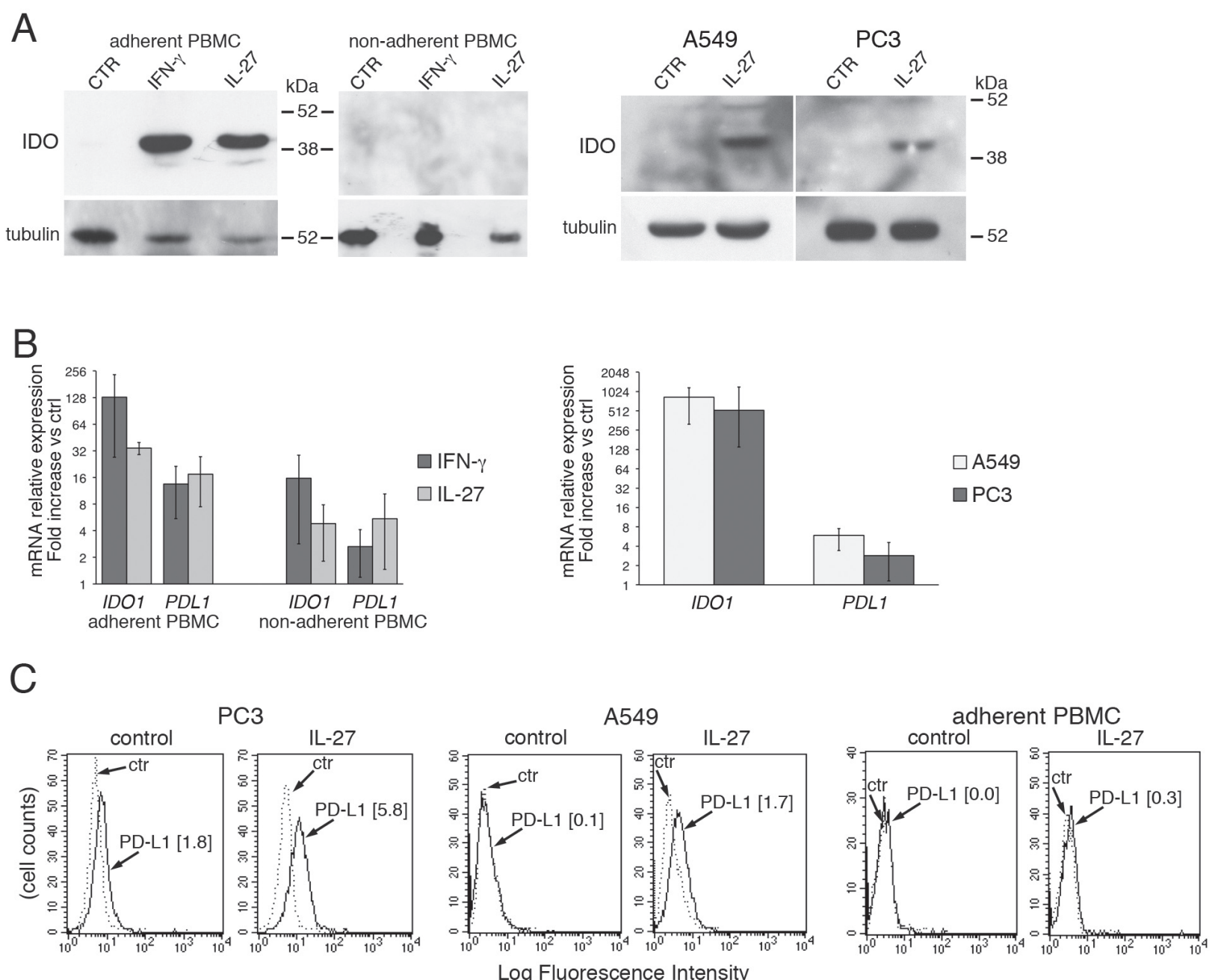

Figure 7: IL-27 induces PD-L1 and/or IDO expression in human PC3 prostate and A549 lung cancer cells and adherent PBMC. A. Western blot analysis of IDO expression in human adherent PBMC, non-adherent PBMC and in PC 3 and A549 cells treated with the indicated cytokines or medium only for 48 hours. $\alpha$-tubulin is used as loading control. Similar results were observed in two additional experiments. B. QRT-PCR analysis of IDO1 and PDL1 mRNA expression in cytokine-stimulated adherent or non-adherent PBMC, PC3 and A549 cells relative to untreated cells. Data are expressed as $\triangle \Delta C T$-fold change. Mean values of three independent experiments. Error bars represent SD. C. FACS analysis of surface PD-L1 in IL-27-treated or untreated PC3 and A549 cell lines and adherent PBMC. Dotted lines are isotype-matched unrelated Ig staining controls. Similar results were obtained in five different experiments (PC3: MFI 5.5 $\pm 2.7 v s$ $1.5 \pm 0.6$, mean \pm SD in IL-27-treated $v s$ un-stimulated cells, $P=0.03$ by paired Student's $t$ test; A549: MFI $2 \pm 1$ vs $0.43 \pm 0.4, P=0.01)$. 


\section{MATERIALS AND METHODS}

\section{Ethics statement}

Investigation has been conducted in accordance with the ethical standards and according to the Declaration of Helsinki and according to national and international guidelines and has been approved by the authors' Institutional Review Board.

Clinical samples and ascitic fluids were collected during surgical procedures before chemotherapeutic treatment from patients who gave written informed consent and used following the Institutional Review Board approval.

\section{Cells and cell treatments}

The human EOC cell lines SKOV3 (ATTC), A2780 (ICLC), OC316 (ICLC), A2774 (IST Genoa), OVCAR5 and the lung carcinoma cells A549 (ATCC) were grown in RPMI 1640, with L-glutamine, 10\% FCS and antibiotics (Lonza). The EOC cell line CAOV3 (INT Milan) was grown in DMEM with L-glutamine, Hepes, $10 \%$ FCS and antibiotics (Lonza). The prostate cancer cells PC3 (ICLC) were grown in HAM'S F-12 with L-glutamine, 10\% FCS and antibiotics (Lonza). A sample of each cell line was recently genotyped using the Cell $\mathrm{ID}^{\mathrm{TM}}$ System (Promega, G9500) and the GeneMapper® software, version 4.0.

Cells were seeded in 24-well plates in culture medium at $50 \times 10^{3}$ cells/well or in 6 -well plates at $150 \times 10^{3}$ cells/well. The day after, culture medium was replaced with medium with or without human recombinant: IFN- $\gamma$ (1,000 IU/ml, PeproTech, 300-02), IL-27, IL-12, IL-11, IL-6 $(100 \mathrm{ng} / \mathrm{ml}, \mathrm{R} \& D$ System, 2526-IL-010, 219-IL005, 218-IL-005, 206-IL-010), IL-35 (100 ng/ml, Enzo Life Sciences, ALX-522-140-C010), IL-30 (100 ng/ml, Abnova, H00246778-P01), EBI3 (100 ng/ml, Novus Biologicals, P4568).

For the analysis of IL-27-induced tyrosinephosphorylated STAT proteins, $5 \times 10^{5}$ EOC cells were incubated for 10 or $30 \mathrm{~min}$ at $37^{\circ} \mathrm{C}$ with or without $20 \mathrm{ng} /$ $\mathrm{ml}$ of IL-27 in $0.5 \mathrm{ml}$ of medium in a test tube. Cells were then rescued by centrifugation and immediately lysed.

PBMC were obtained from buffy coats by Lympholyte-H (Cedarlane, CL5020) density gradient centrifugation. After recovery and washings, PBMC were resuspended in RPMI 1640 supplemented with 4\% $\mathrm{AB}$ serum, plated $\left(10^{7}\right.$ cells $\left./ 2 \mathrm{ml}\right)$ into 6 -well plates and incubated for 2 hours at $37^{\circ} \mathrm{C}$ in $5 \% \mathrm{CO}_{2}$. Non-adherent cells were then removed and plated into new wells. Wells with adherent cells were supplemented with fresh medium. Both cell fractions were cultured for additional $48 \mathrm{~h}$ in the presence or absence of IL-27 (100 ng/ml) or IFN- $\gamma(1,000$ $\mathrm{IU} / \mathrm{ml}$ ). Adherent cells consisted of $>60 \%$ of $\mathrm{CD} 14+$ monocytes as detectect by FACS analysis with FITClabelled anti-CD14 mAb (not shown).

\section{Western blot analysis}

Cells, detached by $2 \mathrm{mM}$ EDTA solution in PBS, were lysed in lysis buffer $(20 \mathrm{mM}$ Tris- $\mathrm{HCl} \mathrm{pH} 7.4$, $1 \mathrm{mM}$ EDTA, $150 \mathrm{mM} \mathrm{NaCl}, 1 \%$ Brij97) containing 2 $\mathrm{mM} \mathrm{Na}$ Orthovanadate and protease inhibitors (Roche Diagnostics, Complete Mini 04693124001). Lysates were resolved under reducing conditions by $10 \%$ SDS-PAGE and analyzed by Western blotting using the following antibodies: anti-IDO murine mAb (Upstate, clone 10.1, 05-840), rabbit anti-phospho-STAT1 (pY701) and antiSTAT1 anti-sera (Cell Signaling Technology, 9167 and 9172, respectively), murine anti-phospho-STAT3 (pY705) and anti-STAT3 mAbs (BD Transduction Laboratories, 612356 and 610190 , respectively), and anti- $\beta$-actin or $\alpha$-tubulin mAbs (Sigma-Aldrich, A2228 and T6074, respectively). Proteins were detected by ECL Prime (GE Healthcare, RPN2232) and autoradiography.

\section{RT-PCR analysis of IDO1 and PDL1 mRNA expression}

Cells were detached by trypsin (Gibco, 12650-010), washed and total RNA was isolated by the NucleoSpin RNA kit (Macherey-Nagel, 740955.250) and reversetranscribed using the SuperScript III Reverse Transcriptase (Invitrogen, 18064-071). Quantitative (Q)RT-PCR analysis was performed using the primers listed in Table S2. Amplification was carried out by the Mastercycler ${ }^{\circledR}$ ep realplex ${ }^{4}$ instrument (Eppendorf International) using the $\mathrm{iQ}^{\mathrm{TM}} \mathrm{SYBR}^{\circledR}$ Green Supermix system (Bio-Rad Laboratories, 170-8882). Relative quantification of mRNAs was calculated by the $\Delta \Delta$ CT method.

\section{Determination of kynurenine concentration}

Conditioned media of IL-27 or IFN- $\gamma$-treated cells were collected, centrifuged, and tested for kynurenine. Samples were extracted with methanol and injected in a high resolution LC-MS/MS system, based on Orbitrap mass spectrometry. The MS/MS condition was used for a SRM quantitative method on kynurenine and the reference ion was the $94.07 \mathrm{~m} / \mathrm{z}$. Calibration curves, ranging from $1 \mu \mathrm{M}$ to $50 \mu \mathrm{M}$, were run on two separate days and constructed from the peak-area of analyte resulting in a linear curve $y=-257013+347555 x$ with a $R^{2}=0.9906$. The samples were prepared at least in duplicate and injected in triplicate. 


\section{Immunofluorescence}

Immunofluorescence with anti-GP130, anti-WSX1/ IL-27RA-PE (R\&D Systems, Clones 28126 and 191115), anti-PD-L1-PE or Isotype Control PE (eBioscience Bender, BMS-125983-41 and BMS-124724-41, respectively) was performed according to manufacturer's instructions. Cell fluorescence was analyzed in a FACScan (Becton\&Dickinson) using the Cell Quest software. Gating on viable cells was performed using physical parameters and $10^{4}$ gated events were acquired.

\section{Small Interfering RNA (siRNA)-mediated STAT1 or STAT3 silencing}

iBONI siRNA-Pool targeting different coding sequences of human STAT1 or STAT3 mRNA or NonTargeting control siRNA pool (RIBOXX Life Science), were transfected in A2774 or OC316 cells using Lipofectamine 2000 Reagent (Invitrogen, 11668-019) in serum-free Opti-MEM medium (Gibco, 51985-026) according to manufacturer's instructions. After overnight incubation the medium was replaced with fresh standard culture medium. The following day, cells were stimulated with cytokines for different time intervals: 10-30 minutes for phosphorylated STAT detection or 48 hours for flow cytometry and Western blot analysis.

\section{Immunohistochemistry}

Detection of IDO, PD-L1 and IL-27 by immunohistochemistry (IHC) was performed on sections of formaldehyde-fixed paraffin-embedded tumors explanted from mice or from 6 high grade serous EOC. Antigen-retrieval was performed with $\mathrm{pH} 6.010 \mathrm{mM}$ citrate buffer (for PD-L1 and IL-27) or $1 \mathrm{mM}$ EDTA, $0.05 \%$ tween $20 \mathrm{pH} 8.0$ buffer (for IDO) in microwave oven. The sections were stained using rabbit anti-IL-27A antibody (LifeSpan BioSciences, LS-B2719-LSBio), antiIDO mAb (Chemicon, clone 10.1, MAB5412) or rabbit anti-PD-L1 antibody (ProSci, 4059) overnight at $4^{\circ} \mathrm{C}$. The antibody complex was revealed with the anti-rabbit or anti-mouse EnVision+ System-Peroxidase (Dako, K4002 and K4000, respectively) and 3-amino-9-ethylcarbazole (Sigma-Aldrich, AEC101-1KT). The sections were counterstained with modified Mayer's ematoxylin solution (Sigma-Aldrich, MHS16) and mounted in Fluoromount Aqueous Mounting Medium (Sigma-Aldrich, F4680). Images were captured with a Nikon Eclipse $80 i$ light microscope equipped with a color camera, using a $40 \mathrm{x}$ objective.

\section{ACKNOWLEDGMENTS AND FUNDING}

Financial support: AIRC (Associazione Italiana per la Ricerca sul Cancro, IG5509, IG13018 and IG13518), Italian Ministry of Health (5 x 1000 Funds 2011 and 2012) and Compagnia di San Paolo.

Grazia Carbotti is recipient of FIRC (Fondazione Italiana per la Ricerca sul Cancro) triennial fellowship 16497.

\section{CONFLICTS OF INTEREST}

The authors have no conflict of interest to disclose.

\section{REFERENCES}

1. Drake CG, Lipson EJ, Brahmer JR. Breathing new life into immunotherapy: review of melanoma, lung and kidney cancer. Nature reviews.Clinical oncology. 2014; 11: 24-37.

2. Eggermont A, Robert C, Soria JC, Zitvogel L. Harnessing the immune system to provide long-term survival in patients with melanoma and other solid tumors. Oncoimmunology. 2014; 3: e27560.

3. Pardoll DM. The blockade of immune checkpoints in cancer immunotherapy. Nature reviews Cancer. 2012; 12: 252-264.

4. Uyttenhove C, Pilotte L, Theate I, Stroobant V, Colau D, Parmentier N, Boon T, Van den Eynde BJ. Evidence for a tumoral immune resistance mechanism based on tryptophan degradation by indoleamine 2,3-dioxygenase. Nature medicine. 2003; 9: 1269-1274.

5. Munn DH. Indoleamine 2,3-dioxygenase, Tregs and cancer. Current medicinal chemistry. 2011; 18: 2240-2246.

6. Topalian SL, Hodi FS, Brahmer JR, Gettinger SN, Smith DC, McDermott DF, Powderly JD, Carvajal RD, Sosman JA, Atkins MB, Leming PD, Spigel DR, Antonia SJ, et al. Safety, activity, and immune correlates of anti-PD-1 antibody in cancer. The New England journal of medicine. 2012; 366: 2443-2454.

7. Brahmer JR, Tykodi SS, Chow LQ, Hwu WJ, Topalian SL, Hwu P, Drake CG, Camacho LH, Kauh J, Odunsi K, Pitot HC, Hamid O, Bhatia S, et al. Safety and activity of antiPD-L1 antibody in patients with advanced cancer. The New England journal of medicine. 2012; 366: 2455-2465.

8. Lavoue V, Thedrez A, Leveque J, Foucher F, Henno S, Jauffret V, Belaud-Rotureau MA, Catros V, Cabillic F. Immunity of human epithelial ovarian carcinoma: the paradigm of immune suppression in cancer. Journal of translational medicine. 2013; 11: 147-5876-11-147.

9. Preston CC, Goode EL, Hartmann LC, Kalli KR, Knutson KL. Immunity and immune suppression in human ovarian cancer. Immunotherapy. 2011; 3: 539-556.

10. Ferrini S, Biassoni R, Moretta A, Bruzzone M, Nicolin A, Moretta L. Clonal analysis of T lymphocytes isolated from ovarian carcinoma ascitic fluid. Phenotypic and 
functional characterization of T-cell clones capable of lysing autologous carcinoma cells. International journal of cancer. 1985; 36: 337-343.

11. Nelson BH. The impact of T-cell immunity on ovarian cancer outcomes. Immunological reviews. 2008; 222: 101116.

12. Sato E, Olson SH, Ahn J, Bundy B, Nishikawa H, Qian F, Jungbluth AA, Frosina D, Gnjatic S, Ambrosone C, Kepner J, Odunsi T, Ritter G, et al. Intraepithelial CD8+ tumorinfiltrating lymphocytes and a high CD8+/regulatory $\mathrm{T}$ cell ratio are associated with favorable prognosis in ovarian cancer. Proceedings of the National Academy of Sciences of the United States of America. 2005; 102: 18538-18543.

13. Hamanishi J, Mandai M, Iwasaki M, Okazaki T, Tanaka Y, Yamaguchi K, Higuchi T, Yagi H, Takakura K, Minato N, Honjo T, Fujii S. Programmed cell death 1 ligand 1 and tumor-infiltrating CD8+ $\mathrm{T}$ lymphocytes are prognostic factors of human ovarian cancer. Proceedings of the National Academy of Sciences of the United States of America. 2007; 104: 3360-3365.

14. Han LY, Fletcher MS, Urbauer DL, Mueller P, Landen CN, Kamat AA, Lin YG, Merritt WM, Spannuth WA, Deavers MT, De Geest K, Gershenson DM, Lutgendorf SK, et al. HLA class I antigen processing machinery component expression and intratumoral T-Cell infiltrate as independent prognostic markers in ovarian carcinoma. Clinical cancer research. 2008; 14: 3372-3379.

15. Webb JR, Milne K, Nelson BH. Location, location, location: CD103 demarcates intraepithelial, prognostically favorable CD8 tumor-infiltrating lymphocytes in ovarian cancer. Oncoimmunology. 2014; 3: e27668.

16. Novick D, Kim SH, Fantuzzi G, Reznikov LL, Dinarello CA, Rubinstein M. Interleukin-18 binding protein: a novel modulator of the Th1 cytokine response. Immunity. 1999; 10: 127-136.

17. Carbotti G, Barisione G, Orengo AM, Brizzolara A, Airoldi I, Bagnoli M, Pinciroli P, Mezzanzanica D, Centurioni MG, Fabbi M, Ferrini S. The IL-18 antagonist IL-18binding protein is produced in the human ovarian cancer microenvironment. Clinical cancer research. 2013; 19: 4611-4620.

18. Leung BS, Stout LE, Shaskan EG, Thompson RM. Differential induction of indoleamine-2,3-dioxygenase (IDO) by interferon-gamma in human gynecologic cancer cells. Cancer letters. 1992; 66: 77-81.

19. Okazaki T, Honjo T. The PD-1-PD-L pathway in immunological tolerance. Trends in immunology. 2006; 27 : 195-201.

20. Spranger S, Spaapen RM, Zha Y, Williams J, Meng Y, Ha TT, Gajewski TF. Up-regulation of PD-L1, IDO, and $\mathrm{T}$ (regs) in the melanoma tumor microenvironment is driven by CD8(+) T cells. Science translational medicine. 2013; 5: 200ra116.

21. Abiko K, Matsumura N, Hamanishi J, Horikawa N,
Murakami R, Yamaguchi K, Yoshioka Y, Baba T, Konishi I, Mandai M. IFN-gamma from lymphocytes induces PDL1 expression and promotes progression of ovarian cancer. British journal of cancer. 2015; 112: 1501-1509.

22. Tumeh PC, Harview CL, Yearley JH, Shintaku IP, Taylor EJ, Robert L, Chmielowski B, Spasic M, Henry G, Ciobanu V, West AN, Carmona M, Kivork C, et al. PD-1 blockade induces responses by inhibiting adaptive immune resistance. Nature. 2014; 515: 568-571.

23. Fang W, Zhang J, Hong S, Zhan J, Chen N, Qin T, Tang Y, Zhang Y, Kang S, Zhou T, Wu X, Liang W, Hu Z, et al. EBV-driven LMP1 and IFN- $\gamma$ up-regulate PD-L1 in nasopharyngeal carcinoma: Implications for oncotargeted therapy. Oncotarget. 2014; 5:12189-202.

24. Vignali DA, Kuchroo VK. IL-12 family cytokines: immunological playmakers. Nature immunology. 2012; 13: 722-728.

25. Li MS, Liu Z, Liu JQ, Zhu X, Liu Z, Bai XF. The Yin and Yang aspects of IL-27 in induction of cancer-specific T-cell responses and immunotherapy. Immunotherapy. 2015; 7: 191-200.

26. Trinchieri G, Pflanz S, Kastelein RA. The IL-12 family of heterodimeric cytokines: new players in the regulation of $\mathrm{T}$ cell responses. Immunity. 2003; 19: 641-644.

27. Pflanz S, Timans JC, Cheung J, Rosales R, Kanzler H, Gilbert J, Hibbert L, Churakova T, Travis M, Vaisberg E, Blumenschein WM, Mattson JD, Wagner JL, et al. IL-27, a heterodimeric cytokine composed of EBI3 and p28 protein, induces proliferation of naive CD4 $+\mathrm{T}$ cells. Immunity. 2002; 16: 779-790.

28. Lucas S, Ghilardi N, Li J, de Sauvage FJ. IL-27 regulates IL-12 responsiveness of naive CD4+ T cells through Stat1dependent and -independent mechanisms. Proceedings of the National Academy of Sciences of the United States of America. 2003; 100: 15047-15052.

29. Cocco C, Giuliani N, Di Carlo E, Ognio E, Storti P, Abeltino M, Sorrentino C, Ponzoni M, Ribatti D, Airoldi I. Interleukin-27 acts as multifunctional antitumor agent in multiple myeloma. Clinical cancer research. 2010; 16: 4188-4197.

30. Zorzoli A, Di Carlo E, Cocco C, Ognio E, Ribatti D, Ferretti E, Dufour C, Locatelli F, Montagna D, Airoldi I. Interleukin-27 inhibits the growth of pediatric acute myeloid leukemia in NOD/SCID/I12rg-/- mice. Clinical cancer research. 2012; 18: 1630-1640.

31. Yoshimoto T, Morishima N, Mizoguchi I, Shimizu M, Nagai H, Oniki S, Oka M, Nishigori C, Mizuguchi J. Antiproliferative activity of IL-27 on melanoma. Journal of immunology. 2008; 180: 6527-6535.

32. Chiba Y, Mizoguchi I, Mitobe K, Higuchi K, Nagai H, Nishigori C, Mizuguchi J, Yoshimoto T. IL-27 enhances the expression of TRAIL and TLR3 in human melanomas and inhibits their tumor growth in cooperation with a TLR3 agonist poly(I:C) partly in a TRAIL-dependent manner. 
PloS one. 2013; 8: e76159.

33. Di Carlo E, Sorrentino C, Zorzoli A, Di Meo S, Tupone MG, Ognio E, Mincione G, Airoldi I. The antitumor potential of Interleukin-27 in prostate cancer. Oncotarget. 2014; 5: 10332-10341.

34. Ho MY, Leu SJ, Sun GH, Tao MH, Tang SJ, Sun KH. IL27 directly restrains lung tumorigenicity by suppressing cyclooxygenase-2-mediated activities. Journal of immunology. 2009; 183: 6217-6226.

35. Hisada M, Kamiya S, Fujita K, Belladonna ML, Aoki T, Koyanagi Y, Mizuguchi J, Yoshimoto T. Potent antitumor activity of interleukin-27. Cancer research. 2004; 64: 11521156.

36. Salcedo R, Stauffer JK, Lincoln E, Back TC, Hixon JA, Hahn C, Shafer-Weaver K, Malyguine A, Kastelein R, Wigginton JM. IL-27 mediates complete regression of orthotopic primary and metastatic murine neuroblastoma tumors: role for CD8+ T cells. Journal of immunology. 2004; 173: 7170-7182

37. Chiyo M, Shimozato O, Yu L, Kawamura K, Iizasa T, Fujisawa T, Tagawa M. Expression of IL-27 in murine carcinoma cells produces antitumor effects and induces protective immunity in inoculated host animals. International journal of cancer. 2005; 115: 437-442.

38. Oniki S, Nagai H, Horikawa T, Furukawa J, Belladonna ML, Yoshimoto T, Hara I, Nishigori C. Interleukin-23 and interleukin-27 exert quite different antitumor and vaccine effects on poorly immunogenic melanoma. Cancer research. 2006; 66: 6395-6404.

39. Swarbrick A, Junankar SR, Batten M. Could the properties of IL-27 make it an ideal adjuvant for anticancer immunotherapy?. Oncoimmunology. 2013; 2: e25409.

40. Aparicio-Siegmund S, Garbers C. The biology of interleukin-27 reveals unique pro- and anti-inflammatory functions in immunity. Cytokine Growth Factor Rev. 2015; 26: 579-86.

41. Awasthi A, Carrier Y, Peron JP, Bettelli E, Kamanaka M, Flavell RA, Kuchroo VK, Oukka M, Weiner HL. A dominant function for interleukin 27 in generating interleukin 10-producing anti-inflammatory T cells. Nature immunology. 2007; 8: 1380-1389.

42. Batten M, Li J, Yi S, Kljavin NM, Danilenko DM, Lucas S, Lee J, de Sauvage FJ, Ghilardi N. Interleukin 27 limits autoimmune encephalomyelitis by suppressing the development of interleukin 17-producing T cells. Nature immunology. 2006; 7: 929-936.

43. Hirahara K, Ghoreschi K, Yang XP, Takahashi H, Laurence A, Vahedi G, Sciume G, Hall AO, Dupont CD, Francisco LM, Chen Q, Tanaka M, Kanno Y, et al. Interleukin-27 priming of $\mathrm{T}$ cells controls IL-17 production in trans via induction of the ligand PD-L1. Immunity. 2012; 36: 10171030.

44. Tanizaki Y, Kobayashi A, Toujima S, Shiro M, Mizoguchi M, Mabuchi Y, Yagi S, Minami S, Takikawa
$\mathrm{O}$, Ino $\mathrm{K}$. Indoleamine 2,3-dioxygenase promotes peritoneal metastasis of ovarian cancer by inducing an immunosuppressive environment. Cancer science. 2014; 105: 966-973.

45. Litzenburger UM, Opitz CA, Sahm F, Rauschenbach KJ, Trump S, Winter M, Ott M, Ochs K, Lutz C, Liu X, Anastasov N, Lehmann I, Hofer T, et al. Constitutive IDO expression in human cancer is sustained by an autocrine signaling loop involving IL-6, STAT3 and the AHR. Oncotarget. 2014; 5: 1038-1051.

46. Ino K. Indoleamine 2,3-dioxygenase and immune tolerance in ovarian cancer. Current opinion in obstetrics \& gynecology. 2011; 23: 13-18.

47. Inaba $\mathrm{T}$, Ino $\mathrm{K}$, Kajiyama $\mathrm{H}$, Yamamoto $\mathrm{E}$, Shibata $\mathrm{K}$, Nawa A, Nagasaka T, Akimoto H, Takikawa O, Kikkawa F. Role of the immunosuppressive enzyme indoleamine 2,3-dioxygenase in the progression of ovarian carcinoma. Gynecologic oncology. 2009; 115: 185-192.

48. Qian F, Villella J, Wallace PK, Mhawech-Fauceglia P, Tario JD,Jr, Andrews C, Matsuzaki J, Valmori D, Ayyoub M, Frederick PJ, Beck A, Liao J, Cheney R, et al. Efficacy of levo-1-methyl tryptophan and dextro-1-methyl tryptophan in reversing indoleamine-2,3-dioxygenase-mediated arrest of T-cell proliferation in human epithelial ovarian cancer. Cancer research. 2009; 69: 5498-5504.

49. Anglesio MS, Wiegand KC, Melnyk N, Chow C, Salamanca C, Prentice LM, Senz J, Yang W, Spillman MA, Cochrane DR, Shumansky K, Shah SP, Kalloger SE, et al. Typespecific cell line models for type-specific ovarian cancer research. PloS one. 2013; 8: e72162.

50. Domcke S, Sinha R, Levine DA, Sander C, Schultz N. Evaluating cell lines as tumour models by comparison of genomic profiles. Nature communications. 2013; 4: 2126.

51. Maine CJ, Aziz NH, Chatterjee J, Hayford C, Brewig N, Whilding L, George AJ, Ghaem-Maghami S. Programmed death ligand-1 over-expression correlates with malignancy and contributes to immune regulation in ovarian cancer. Cancer immunology, immunotherapy. 2014; 63: 215-224.

52. Duraiswamy J, Freeman GJ, Coukos G. Therapeutic PD-1 pathway blockade augments with other modalities of immunotherapy T-cell function to prevent immune decline in ovarian cancer. Cancer research. 2013; 73: 6900-6912.

53. Abiko K, Mandai M, Hamanishi J, Yoshioka Y, Matsumura N, Baba T, Yamaguchi K, Murakami R, Yamamoto A, Kharma B, Kosaka K, Konishi I. PD-L1 on tumor cells is induced in ascites and promotes peritoneal dissemination of ovarian cancer through CTL dysfunction. Clinical cancer research. 2013; 19: 1363-1374.

54. Krempski J, Karyampudi L, Behrens MD, Erskine CL, Hartmann L, Dong H, Goode EL, Kalli KR, Knutson KL. Tumor-infiltrating programmed death receptor-1+ dendritic cells mediate immune suppression in ovarian cancer. Journal of immunology. 2011; 186: 6905-6913.

55. Sotero-Esteva WD, Wolfe D, Ferris M, Taylor MW. An 
indoleamine 2,3-dioxygenase-negative mutant is defective in stat1 DNA binding: differential response to IFN-gamma and IFN-alpha. Journal of interferon \& cytokine research. 2000; 20: 623-632.

56. Kharma B, Baba T, Matsumura N, Kang HS, Hamanishi J, Murakami R, McConechy MM, Leung S, Yamaguchi K, Hosoe Y, Yoshioka Y, Murphy SK, Mandai M, et al. STAT1 drives tumor progression in serous papillary endometrial cancer. Cancer research. 2014; 74: 6519-6530.

57. Marzec M, Zhang Q, Goradia A, Raghunath PN, Liu X, Paessler M, Wang HY, Wysocka M, Cheng M, Ruggeri BA, Wasik MA. Oncogenic kinase NPM/ALK induces through STAT3 expression of immunosuppressive protein CD274 (PD-L1, B7-H1). Proceedings of the National Academy of Sciences of the United States of America. 2008; 105: 20852-20857.

58. Mantovani A, Allavena P. The interaction of anticancer therapies with tumor-associated macrophages. J Exp Med. 2015; 212: 435-45.

59. Zhao Q, Kuang DM, Wu Y, Xiao X, Li XF, Li TJ, Zheng L. Activated CD69+ $\mathrm{T}$ cells foster immune privilege by regulating IDO expression in tumor-associated macrophages. Journal of immunology. 2012; 188: 1117 1124.

60. Chon SY, Hassanain HH, Gupta SL. Cooperative role of interferon regulatory factor 1 and p91 (STAT1) response elements in interferon-gamma-inducible expression of human indoleamine 2,3-dioxygenase gene. The Journal of biological chemistry. 1996; 271: 17247-17252.

61. Yu J, Wang Y, Yan F, Zhang P, Li H, Zhao H, Yan C, Yan F, Ren X. Noncanonical NF-kappaB activation mediates STAT3-stimulated IDO upregulation in myeloid-derived suppressor cells in breast cancer. Journal of immunology. 2014; 193: 2574-2586.

62. Mascanfroni ID, Yeste A, Vieira SM, Burns EJ, Patel B, Sloma I, Wu Y, Mayo L, Ben-Hamo R, Efroni S, Kuchroo VK, Robson SC, Quintana FJ. IL-27 acts on DCs to suppress the $\mathrm{T}$ cell response and autoimmunity by inducing expression of the immunoregulatory molecule CD39. Nature immunology. 2013; 14: 1054-1063.

63. Batten M, Kljavin NM, Li J, Walter MJ, de Sauvage FJ, Ghilardi N. Cutting edge: IL-27 is a potent inducer of IL-10 but not FoxP3 in murine T cells. Journal of immunology. 2008; 180: 2752-2756.

64. Sekar D, Hahn C, Brune B, Roberts E, Weigert A. Apoptotic tumor cells induce IL-27 release from human DCs to activate Treg cells that express CD69 and attenuate cytotoxicity. European journal of immunology. 2012; 42: 1585-1598.

65. Canale S, Cocco C, Frasson C, Seganfreddo E, Di Carlo E, Ognio E, Sorrentino C, Ribatti D, Zorzoli A, Basso G, Dufour C, Airoldi I. Interleukin-27 inhibits pediatric B-acute lymphoblastic leukemia cell spreading in a preclinical model. Leukemia. 2011; 25: 1815-1824.
66. Shimizu M, Shimamura M, Owaki T, Asakawa M, Fujita K, Kudo M, Iwakura Y, Takeda Y, Luster AD, Mizuguchi J, Yoshimoto T. Antiangiogenic and antitumor activities of IL-27. Journal of immunology. 2006; 176: 7317-7324.

67. Airoldi I, Tupone MG, Esposito S, Russo MV, Barbarito G, Cipollone G, Di Carlo E. Interleukin-27 re-educates intratumoral myeloid cells and down-regulates stemness genes in non-small cell lung cancer. Oncotarget. 2015; 6: 3694-3708.

68. Fabbi M, Carbotti G, Ferrini S. Context-dependent role of IL-18 in cancer biology and counter-regulation by IL-18BP. Journal of leukocyte biology. 2015; 97: 665-675.

69. Croce M, Rigo V, Ferrini S. IL-21: a pleiotropic cytokine with potential applications in oncology. Journal of immunology research. 2015; 2015: 696578. 